\title{
CD2 Antigen Cytoplasmic Tail-Binding Protein 2
}

National Cancer Institute

\section{Source}

National Cancer Institute. CD2 Antigen Cytoplasmic Tail-Binding Protein 2. NCI

Thesaurus. Code C126502.

CD2 antigen cytoplasmic tail-binding protein 2 (341 aa, $\sim 38 \mathrm{kDa}$ ) is encoded by the human CD2BP2 gene. This protein plays a role in mRNA splicing and T-cell activation. 